Socialist Studies: the Journal of the Society for Socialist Studies 6(1) Spring 2010:125-136

Copyright (C) 2010 The Author(s)

SPECIAL SECTION

TWENTY YEARS AFTER KANEHSATÀ:KE: REFLECTIONS, RESPONSES, ANALYSES

\title{
The Kahnawá:ke Standoff and Reflections on Fascism
}

\section{DAVID BEDFORD \& THOMAS CHENEY}

Political Science, University of New Brunswick. Fredericton, New Brunswick, Canada

Political Science, University of Victoria. Victoria, British Columbia, Canada

\begin{abstract}
This article offers a critical interpretation of the state and media reactions to the crisis at Oka, Québec in the summer of 1990. Drawing on Marx's analysis of Bonapartism, or fascism, it is argued that the Canadian state was willing to use excessive force to suppress the Mohawk dissidents. Its fascist methods also included racial demonizing and using the basest impulses of angry crowds to intimidate Natives. Mainstream media sources played an unmistakable role in channelling this racist violence against the rebelling Aboriginals. The function of competing nationalisms (Mohawk, Québécois and Canadian) in this episode is analyzed as well. It is argued that solidarity between the working class and the Mohawks may have resulted in a more positive outcome of the conflict. A renewed set of relations between the Canadian left and Aboriginals could reveal constructive ways forward for groups struggling under the weight of capitalist society and its state.

Résumé

Cet article offre une interprétation critique des réactions de l'Etat et des médias à la crise de Oka, Québec dans l'été 1990. Utilisant l'analyse que Marx avait faite du Bonapartisme ou fascisme, il suggère que l'Etat canadien était prêt à employer une force excessive afin de supprimer les dissidents
\end{abstract}

\footnotetext{
David Bedford is professor of political science at the University of New Brunswick. He has written on various issues of Aboriginal politics, including: the relation of the left to the Aboriginal struggle; Aboriginal voter turnout; and the Great Law of Peace as an International Relations document. He teaches in the area of Political Philosophy and Aboriginal Politics. Thomas Cheney holds a Bachelor of Arts in Political Science from the University of New Brunswick. He is entering the Master's program in Political Science at the University of Victoria, focussing on political theory and environmental issues.

David Bedford est professeur de science politique à l'Université du Nouveau Brunswick. Il a écrit sur plusieurs aspects de la politique Autochtone, y compris : la relation de la gauche avec la lutte Autochtone; la taux de participation des Autochtones aux élections; et la Grande Loi de la Paix en tant que document de Relations Internationales. II enseigne dans le domaine de la philosophie politique et la politique autochtones. Thomas Cheney a un BA en science politique de l'Université de Nouveau Brunswick. Il entre dans le programme de Masters en science politique à l'Université de Victoria, avec une spécialisation sur la théorie politique et les questions environnementales.
} 
Socialist Studies: the Journal of the Society for Socialist Studies 6(1) Spring 2010: 125-136

Mohawk. Ses méthodes fascistes incluaient la diabolisation raciale et l'utilisation des pires impulsions des foules en colère afin d'intimider les Autochtones. Les médias dominants ont joué un rôle indubitable en canalisant cette violence raciste contre les Autochtones rebelles. La fonction des nationalismes rivaux (Mohawk, Québécois et Canadien) dans cet épisode est également analysée. Cet article défend que la solidarité entre la classe ouvrière et les Mohawk aurait pu aboutir à un résultat plus positif du conflit. Des relations renouvelées entre la gauche Canadienne et les Autochtones pourrait révéler des voies constructives pour des groupes luttant sous le poids de la société capitaliste et son Etat.

Keywords

- Oka • Kahnawáke • Aboriginal • state • class • fascism

Mots clés

- Oka • Kahnawáke • Autochtone • état • classe • fascisme

On 11 July 1990 the city of Montréal discovered that the crisis at Oka, Québec had taken a new and dramatic turn. The Mohawk Community at Kahnawá:ke had blockaded the Mercier Bridge and Highway 132, both important commuter routes from the suburban communities on the South Shore to the island of Montréal. Morning commutes that normally took thirty minutes were going to take two to three hours. The question of Mohawk land claims now occupied centre stage of Québec and Canadian politics.

The blockades of July and August set in motion events that would demonstrate clearly the character of the Canadian polity and the extent to which the fascist propensities of the capitalist state under threat lie just below the surface. As Canada had previously revealed its hidden face, both before and during World War II when it failed to do anything to protect the Jews of Europe (or Canada), and when it had turned on its citizens of Japanese ethnicity, confiscating their property, imprisoning them and then refusing them the right to return to their homes in British Columbia, so it would, once again, make use of tried and true fascist techniques in suppressing Mohawk resistance. The use of state forces of repression, targeting of whole populations, unleashing the lowest impulses of the crowds as an unofficial form of state intimidation, the silencing of the media and, finally, channelling labour militancy into reactionary nationalism are all hallmarks of a nascent fascism and were all critical tools in the suppression of the Mohawks.

Fascism has been interpreted in various ways. Analysts on the Left generally draw their theoretical inspiration from Marx's Eighteenth 
BEDFORD \& CHENEY: The Kahnawá:ke Standoff and Reflections on Fascism

Brumaire of Louis Bonaparte. For Marx, Bonapartism, or fascism, originates in a bourgeois social formation where class tensions are so great that the bourgeoisie cannot rule directly and in the open. Instead, they must hide behind an ideology that masks class rule and that appeals across class lines, thus creating a broad consensus. (Marx 1972,19) Appeals to God and country, peace, order and good government, as well as nationalism, and racial demonizing are frequent tactical choices. All were used in targeting Japanese Canadians. The Québec bourgeoisie, faced with militant and left-leaning labour unions in the late 1960s and early 1970s used nationalism to diffuse class antagonism and to forge a consensus around the agenda of nation-building through supporting and developing a Québec-based bourgeoisie.

Fascism is, in addition to its functional definition in terms of class rule, also identified by the methods it employs. These were especially conspicuous in the state's reaction to the Oka and Kahnawá:ke blockades. ${ }^{1}$ Intimidation in place of debate, 'debate' itself reduced from rational discourse and exchange of ideas to simple demagogic chants, demonizing stereotypes and scapegoating targeted populations are all fascist techniques. Most especially for this paper, fascism also involves enlisting important sections of the subordinate classes in intimidating the demonized. The result is a class politics that is devoid of rational content in the configuration of class interest and activity, and equally devoid of rational content in its sociological analysis. What is of interest to the left as we reflect on the lessons of Oka twenty years later was how easily the democratic state revealed its fascist face, how equally easy it was to enlist mobs to help in the intimidation, how lacking in class solidarity was organized labour, and how ineffective the left was in re-orienting the popular narrative.

Let us begin by examining the various ways in which the Mohawk population was a target for intimidation. Of course, most in evidence was the military and police blockading of the Kahnawá:ke Reserve. Three layers of roadblocks were set up. Closest to the reserve was the army. Next, was the Sûreté du Québec roadblock, followed by local police who

\footnotetext{
${ }^{1}$ The reason for the response to the Mohawk blockade was not immediately class-based. Although largely proletarian the Mohawks were challenging the status quo of property and order as aboriginals, not primarily as workers. The state's reaction, however, is indicative of its role as defender of property and as creating the conditions for accumulation, both of which were threatened by the blockade. As well, generalized repression, even surplus repression, characterizes the bourgeois state.
} 
were accompanied by hostile crowds. Military planes regularly buzzing the community, razor-wire, cannons aimed at the community, occasional instances of tear-gassing, and regular manoeuvres set a climate of anxiety. Food shipments were interdicted, leaving the people fearful of starvation, even as John Ciaccia, Québec Native Affairs Minister, was insisting that no such restrictions existed. Claude Ryan, a senior minister and former Liberal leader, later admitted that it was indeed government policy (York and Pindera 1991, 211).

Kahnawá:ke is serviced by Kateri Memorial Hospital. With one exception, all the physicians who worked there were non-native and lived off-reserve. ${ }^{2}$ As they were the only people allowed by either side to go to and from the reserve their treatment is an especially interesting test case. At first the Kateri physicians crossed over the blockaded Mercier Bridge, stopping at each of the road-blocks to show proper documentation, to answer questions, to have their vehicles searched, even to have lunches and any extra food confiscated. Eventually they were prohibited from taking this route and went to the reserve through a series of back roads, again running the gauntlet of road-blocks. This route, too, was finally closed by the state and more inventive means had to be found to get to Kateri and to look after patients who, as the crisis wore on, were increasingly suffering from ill health. Stress and fear had especially negative effects on people with chronic illnesses such as asthma, diabetes, heart conditions and so on.

Minister Ciaccia then arranged for the physicians to travel by boat. Mohawk Peacekeepers, the local reserve police force, would pick the doctors up from a dock in Dorval and take them across the St. Lawrence River. This soon drew the attention of local media, in particular Gilles Proulx of the radio station CJMS, who encouraged the crowd to prevent the doctors from embarking from the public dock. The local police did nothing to stop the crowds from forming, and so a private dock was used for a few days but this too was blocked by the crowds. Finally, an ambulance driver from Urgences Santé volunteered to drive and escort doctors through the roadblocks on the Mercier Bridge and through the crowds who were by now determined not to let the people of Kahnawá:ke get medical services. Although in the end the state (and the mobs that it permitted to form) was unsuccessful in preventing the physicians from staffing Kateri Memorial

\footnotetext{
${ }^{2}$ What follows is based upon personal communications with a number of the physicians involved.
} 
BEDFORD \& CHENEY: The Kahnawá:ke Standoff and Reflections on Fascism

Hospital and from providing vital health-care services to the people of Kahnawá:ke, the attempts at intimidation left no doubt about the tactics it was willing to use.

Of interest is the way that the crowd behaved and the police complicity in it. Notable were the riots of early August when thousands from Chateauguay, perhaps the most affected South Shore community, gathered near their border with Kahnawá:ke shouting racial epithets and burning an effigy of a Mohawk, in a 'celebration' reminiscent of the Ku Klux Klan and Nazi Germany. (York and Pindera 1991, 250) As well, however, doctors and their patients were subject to regular harassment as police stood by and watched. Crowds regularly blocked cars that doctors drove, threatening and insulting the physicians, even trying to overturn them and get inside. In one especially ghoulish incident, a Mohawk woman was being rushed by ambulance to the Montréal General Hospital, with a gynaecological emergency. The crowd stopped the ambulance and after heated discussion with the driver, and with police complicity, looked inside, even removing the sheets covering the woman to verify that she was, in fact, bleeding.

Most dramatic and tragic was the incident of August 28 when a convoy of sick and elderly who needed to be removed from the reserve were stoned by a crowd as they left the Mercier Bridge and crossed into LaSalle. Cars were pelted with a hail of stones, their windows smashed, leaving one man dead, twelve injured and hundreds terrified. These facts are well known. Less well known is the surrounding story. The police were informed that the motorcade was on its way. Despite potential danger from angry crowds the police held the cars up for two hours on the Mercier Bridge for no reason. In the meantime, the notoriously antiMohawk Gilles Proulx was notified and he announced on his show that a crowd should gather to prevent the cars from getting off the bridge and away from the reserve. As the minutes turned into hours hundreds had gathered. Once the mob had fully assembled and had time to arm themselves with stones, bricks and cement blocks from the nearby construction site, the police ordered the cars through, making no attempt to protect the Mohawks or stop the crowd from stoning them. The Mohawk ambulance accompanying the convoy and carrying an attending physician was prohibited by police from exiting the bridge leaving the physician and an ambulance driver to walk along the road through the crowd, without police protection.

Even though the event was filmed only three persons were charged. The cases were finally decided the following year. Yvon Breault pleaded 
guilty and was given an unconditional discharge. Stephane Vincke and Jean-Louise Lizotte were also given discharges after agreeing to donate $\$ 500$ each to charity. Judge Chaloux was concerned not to give them a criminal record because a felony conviction would prevent them from pursuing their chosen careers. Lizotte wanted to be a security guard and Vincke had already enlisted in the Canadian Army. (Gazette 30 April 1991, A4) To see the true character of the state, even the Canadian state, one need only imagine the response of the courts to charges against union members who stoned a convoy of scabs, killing one and injuring twelve, or a group of anarchist youth stoning a procession of bankers. It is also inconceivable that the police would simply stand by and watch the events unfold, doing nothing to prevent it.

Predictably, the mainstream media acted as a propaganda arm of the state, targeting the Mohawks for reprisals. The Montréal Gazette, the dominant English language newspaper, as well as La Presse strove to discredit the Warrior Society and many of the Native leaders guiding the protests at Kanehsatà:ke and Kahnawá:ke . These media outlets also endeavoured to instil in the non-Native population a fear of widespread Native revolt throughout Canada, ultimately providing the justification for the use of state force against the Aboriginal dissidents. While these press sources did not question the validity of the Native complaints against the Canadian state, they persistently decried the methods chosen by the Native protesters as inappropriate and described them as 'foul-mouthed people throwing stones, wearing costumes and brandishing guns....' (Gazette 21 Sept. 1990, B3)

One of the main aims of the media was to consistently bring into disrepute the Warrior Society itself. Headlines such as 'Less like Warriors than thugs' were featured in the Montréal Gazette (17 July 1990, B2), while La Presse proclaimed on 'Le grand rêve fou des Warriors'- 'The insane dream of the Warriors' (25 Aug. 1990, B2). The goals and credibility of the Warrior society were always cast in a negative light, no doubt to bring the validity of the entire protest into question. Lysiane Gagnon, in an article published in La Presse, suggested that they might have connections to the Mafia. (Aug. 1990, B3) Further, attempts were clearly made to show that the Native protest as a whole suffered from disunity and was divided into many factions. (Gazette 12 July 1990, A1) In this way, their intentions were brought into question:by portraying the Native protesters as fractured and incapable of internal coherence, the legitimacy of their demands could be negated. 
BEDFORD \& CHENEY: The Kahnawá:ke Standoff and Reflections on Fascism

More striking than the attempts to associate the Warriors with organized crime or to discredit their goals, were the deliberate attempts to inculcate in the non-Native population a fear of the Warrior Society and of all Native people. Thus, headlines such as 'Defiant Mohawks dig in; Indians threaten to blow up Mercier Bridge if attacked again' (Gazette 12 July 1990, A1) appeared in the Montréal Gazette, and La Presse compared the Warrior Society to the Front de Libération du Québec . (28 Aug. 1990, B3) The immediate threat of violence in Kanehsatà:ke and Kahnawá:ke was drilled into the minds of readers of La Presse, which dramatically announced that the Mayor of Châteauguay, Jean-Bosco Bourcier, had asked for Prime Minister Brian Mulroney to intervene in the conflict. (La Presse 16 July 1990, A1) Moreover, the Montréal Gazette pronounced that there was an imminent threat of Native uprising on a national level: 'Oka's agony may be just the start; Militant natives across Canada seem ready to take up arms.' (Gazette 14 July 1990, B1) Sensationalized reporting on the threat of unrest, an implicit call for order, dominated the media coverage of the Oka crisis.

In the Eighteenth Brumaire Marx held that during the 1848 revolutions in France 'all classes and parties had united in the Party of Order against the proletarian class as the party of anarchy.... They had given out the watchwords of the old society, "property, family, religion, order," to their army as passwords...' (Marx 1972,19) Just as the subordinate classes were incited against the proletariat in 1848, in 1990 they were stirred to impose 'order' on the rebelling Natives. The selective reporting of the media played a distinct role in these alarming outbursts of racist violence - by legitimating and even encouraging it. When Mayor Bourcier announced that it would be best to simply let the angry crowd 'vent its anger,' the Montréal Gazette was sure to spread the word that Chateauguay's mayor was endorsing activities reminiscent of those of the KKK: 'Chateauguay Mayor Jean-Bosco Bourcier says it's best to let the rowdies gathering nightly at the Kahnawá:ke barriers carry on with their chanting and effigy-burning' (Gazette 19 July 1990, A5). Irrationality on such a scale brings to mind Hannah Arendt's warning of the grave dangers and the potential fascism of a situation in which rational discourse is not present. (Arendt 2006) Those participating in the burring of Native effigies and other violent, racist acts were certainly not immersed in any sort of rational discourse and the media had a definite role to play in this fact.

Dispiritingly there was no response by organized labour. One would have hoped for a greater sense of class consciousness and an intuition that the same state that unleashed its repressive forces on the 
Mohawks would just as easily and quickly turn on labour if it ever dared step out of its place. Blockades by labour, mass and flying pickets, hotcargoing, which were all common tactics by labour in earlier decades, had now all been gradually legislated away by the state. Here was an opportunity to reassert itself as a militant labour movement, just as they were in the late 1960s and 1970s.

The power of armed resistance, especially against fascism, was demonstrated in the Christie Pits riot in 1933. Through the summer Nazi groups in Toronto had targeted the Jewish community. This came to head on 16 August when, at a baseball game in which one team was largely Jewish, racist chants were raised and a Swastika unfurled. Enraged, the Jewish players attacked and this set off a street brawl that lasted for hours. Interestingly, as more people entered in the battle the Jewish fighters were joined by contingents of Italian and Ukrainian working class youth. Any other antipathy that they might have felt was overwhelmed by the solidarity that comes from a common enemy. The fascist movement (and Anglo-Torontonian chauvinism) took aim at all immigrants, at organized labour and left politics, and the Jewish, Italian, and Ukrainian communities shared these characteristics.

Levitt and Shaffir described the context for the riots in their book The Riot at Christie Pits. 'Not surprisingly, the Depression polarized society into warring camps. A number of unemployed and working-class people joined or passively supported radical movements... In Toronto, anti-communism was thus inextricably intertwined with xenophobia and anti-semitism'. (Levitt and Shaffir 1987, 23) What Levitt and Shaffir point out was the easy identification of targets - linking anti-immigration, antisemitism and anti-communism - making solidarity between such groups a natural response. 'The anti-communist crusade started a chain reaction that created some of the pre-conditions for the Christie Pits riot five years later. First, it intensified the identification in the minds of many between Communism and Jews. It emphasized the foreignness of the immigrants' (Levitt and Shaffir 1987, 26).

So, while the Québec labour movement may not have sympathized with protecting a pine forest from the expansion of a golf course, they certainly knew about the state repression from the October Crisis, from the gradual erosion of rights and from the threat of prison when militant action was taken.

Why was there little, if any, solidarity between labour and the Aboriginal struggle for justice? This is a complex and many-sided question. In part, it is because labour sees Aboriginal communities as standing in the 
BEDFORD \& CHENEY: The Kahnawá:ke Standoff and Reflections on Fascism

way of business. Protected forests mean fewer jobs; Aboriginal fishers mean fewer non-native ones; Aboriginals are portrayed in the media as unemployed, non-tax-paying drains on 'our' tax dollars. However, in part the answer is the construction of Aboriginals as the other, as a competing national identity which threatens and rejects Canadian/Québec national identity. In Québec, in particular, Mohawks were described in grade school texts as anti-French, as English allies in the French-English Wars, as English speaking, as the savage killers of Father Brébeuf. Further, their assertion of Mohawk sovereignty challenged the legal basis of Québec sovereignty, even as it similarly challenged that of Canada.

Part of the explanation, however, rests with the unique history of Québec labour, a story which is revealing of the ease with which even militant unions can be derailed. By the early 1970s, Québec's labour movement was among the most radical ever seen in Canada. The high point was the general strike of May 1972, which resulted in brief prison terms for the leaders of the Confederation of National Trade Unions (CNTU), Fédération des travailleurs du Québec (FTQ) and the teachers union. The elective victory of 1976 by the Parti Québécois (PQ) was significantly premised on a social democratic platform and on the argument that in a more conservative Canadian political climate labour could prosper only through sovereignty. The $P Q$, however, soon drifted rightward. Interestingly, however, the PQ under Levesque was much more sympathetic to Aboriginal aspirations than the Québec Liberal Party (PLQ).

By this time, though, the labour movement was fully tied to the nationalist project. The resistance to both sovereignty and the language restrictions by the Anglophone and Allophone communities led to a further alienation between the nationalisms of Québec and Canada. Caught up in this were First Nations, who by tradition and treaty identified with the Canadian state as the continuation of the British Crown, and who commonly spoke English and not French. There were also flashpoints such as raids on Restigouche, the Mi'kmaq community on the New Brunswick border, and in Kahnawá:ke itself by the Sûreté du Québec. As a result, layered over the usual anti-aboriginal sentiments that shamefully mark all of Canada, was added the level of competing national identities, as Mohawks asserted their sovereignty and their identity as Mohawk perhaps even on occasion as Canadian - but certainly not as Québécois.

While the narrative of competing nationalisms was certainly true, the real tragedy of the Oka Crisis and the Kahnawá:ke standoff was that this narrative crowded out all other interpretations in the public mind. The emphasizing of identity politics at the expense of class analysis by 
academics and public intellectuals disarms the working class. Of course, academics are often simply following a trend, or they are over-emphasizing one aspect of reality to highlight an ignored element for example, but the consistent re-presentation of tensions between Aboriginal communities and Québec as competing national identities did little to prevent the rise of national chauvinisms and hatreds. ${ }^{3}$

An alternative narrative of the Aboriginal place in non-aboriginal Canadian society can reveal constructive ways forward that help create alliances between groups struggling under the weight of capitalist society and its state. Howard Adams, the noted Métis writer, has perhaps more than most in Canada explored the roots of Aboriginal oppression and exploitation in the bourgeois property form. Historically the left in Canada has not offered nuanced or inclusive analyses of the 'aboriginal question' (Bedford and Irving 2001). Most have begun from the analytical premises of the Marxist approach of the Second International which saw the way forward to socialism only through the complete expansion of capitalist relations and the maximization of societal riches. These premises left little room in the struggle against exploitation for Aboriginals who were not members of the proletariat. Adams' work on the internal governance of Aboriginal communities and the place of Aboriginals in contesting dominant social and political relations provides an important left alternative to the overly mechanistic Marxism and to the national identities reading that have dominated left discourse on this question to date (Adams 1995).

The events of the summer of 1990 reveal to us just how close to the surface fascism is. The bourgeois state can at a moment's notice drop the facade of democratic procedures, human rights and civil liberties. ${ }^{4}$ The army, it must not be forgotten, is easily turned from international peacekeeping to preserving the domestic status quo of property rights and state sovereignty. Tear gas, which would not be used on foreign enemies, is turned on women and children without a second thought. There are also latent fascist sympathies within the populace which can easily be brought to the surface. A few weeks of traffic jams and a demagogue like Proulx

\footnotetext{
${ }^{3}$ Ellen Wood $(1983,241)$ argued that the de-centring of class in Marxism stemmed from the popular front policies of Euro communism. In Canada the appeal of Canadian nationalism has been a contributing factor (Workman, 139).

${ }^{4}$ We certainly do not mean to argue that there is no real difference between state forms, i.e. that a liberal-democratic and a fascist state are the same. We do argue, however, that fascist methods are easily resorted to, and so we call these actions proto or nascent fascism.
} 
BEDFORD \& CHENEY: The Kahnawá:ke Standoff and Reflections on Fascism

could encourage the most foul behaviour from his listeners. There are plenty of Proulxes and they have no difficulty finding targets and mobs to do their bidding. The summer of 1990 was sobering for all on the left and for anyone who held to the illusions of Canadian gentility and exceptionalism.

In the end what lessons can be learned from the Oka Crisis? The failure of the many attempts that were made to rally support for the Mohawks shows that the fundamental truth of Marxist political praxis still holds. Only the power of organized labour can effectively counter the repressive forces of the state. While the many demonstrations of sympathy that were held did nothing to dissuade Bourassa and Mulroney, the truckers' union could have forced a quick and honourable end if they blocked all of Québec 's roads. Additionally, organized labour's support has a social meaning that occupies a more central place in public discourse and understanding than does the support of an eclectic mix of pro-Native sympathizers who can be dismissed as ideological oddities. However, to do this labour must not be sidetracked by protectionisms, nationalisms, racism and so. They must centre the class question, as only thus can they be the locus for solidarity. While they differ from the Mohawks in many ways they share a common oppression and oppressor. The internationalism that Marx argued for, and that rested at the heart of the early international labour movement, must be re-centred and extended to include all, even within the Canadian and Québec nations.

But how can this return to an earlier consciousness of trans-group solidarity be made? The answer can be found in a critique of the left over the past forty or fifty years. As we have lived through a seemingly endless series of 'Anybody but Johnson, Nixon, Reagan, Bush etc.', we witness a Left which now argues 'ABC - anything but class'. What is needed more than anything is a (re) formed Left in which the principles which can forge an alternative to the bourgeois state are rationally debated. Instead of the fleeting passions of national identity and chauvinism we need a reasoned analysis. As political scientist Thom Workman has written in his recent reevaluation of the Left: 5

Capitalism is troubling, and these emotions can carry us away. An ethos of reflection and contemplation will assuage the welter of emotions experienced by everyone, effectively absorbing our emotional distresses about capitalist life into a patient and reflective standpoint. A properly

\footnotetext{
${ }^{5}$ See the Govind C. Rao's review of Workman in this issue.
} 
Socialist Studies: the Journal of the Society for Socialist Studies 6(1) Spring 2010: 125-136

formed left culture is not unlike a properly formed Platonic soul, the soul where the faculty of reason governs the spiritedness and passion of our being. Passions are a part of life, but in capitalist society they can overtake us and must be massaged by reason, contemplation and sustained reflection. (Workman 2009, 134)

\section{References}

Adams, Howard. 1995. A Tortured People: The Politics of Colonization. Penticton: Theytus.

Arendt, Hannah. 2006. Eichmann in Jerusalem. New York: Penguin Books.

Bedford, David and Dan Irving. 2001. The Tragedy of Progress: Marxism, Modernity and the Aboriginal Question. Halifax: Fernwood Publishing.

Levitt, Cyril and William Shaffir. 1987. The Riot at Christie Pits. Toronto: Lester and Orpen Dennys.

Marx, Karl. 1972. The Eighteenth Brumaire of Louis Bonaparte. Moscow: Progress Publishers.

Wood, Ellen Meiksins. 1983. "Marxism Without Class Struggle?" Socialist Register 20: 239271.

Workmam, Thom. 2009. If You're in My Way I'm Walking: The Assault on Working People Since 1970. Halifax: Fernwood Publishing.

York, Geoffery and Loreen Pinder. 1991. People of the Pines: The Warriors and the Legacy of Oka. Toronto: Little, Brown and Co. (Canada). 